BIOMEDICAL AND BIOSOCIAL ANTHROPOLOGY
$\begin{gathered}\text { Official Journal of the International Academy } \\ \text { of Integrative Anthropology } \\ \text { journal homepage: http://bba-journal.com }\end{gathered}$

\title{
Indicators of emotional burnout of pupils at the age of 15-17 years old and their dynamic changes during period of study in a modern school
}

Serheta I. V., Bratkova O. Yu., Panchuk O. Y., Skoruk R. V., Shevchuk Yu.G.

National Pirogov Memorial Medical University, Vinnytsya, Ukraine

ARTICLE INFO
Received: 26 August, 2020
Accepted: 30 September, 2020

UDC: 613:616-053.82:378

\section{CORRESPONDING AUTHOR}

e-mail: serheta@gmai.com Serheta I. V.

\begin{abstract}
Burnout-syndrome is a state of physical, motivational and, above all, emotional exhaustion, which is characterized by impaired productivity/education, the presence of severe fatigue, insomnia and increased susceptibility to the formation of somatic diseases, as well as the use of psychoactive substances, in order to obtain temporary relief, which has a pronounced tendency to develop psychological or physiological dependence and the formation of suicidal behavior. The purpose of the work is to determine the leading indicators of emotional burnout of pupils aged 15-17 years and to establish the features of their dynamic changes during education in a modern school. The research using Boyko's personal questionnaire was conducted on the basis of a number of secondary schools located in Vinnytsia, during which 309 pupils (158 young women and 151 young men) at the age of 15-17 years old were supervised. The analysis of the obtained data involved the application of descriptive statistics procedures based on the use of the standard package of statistical analysis applications "Statistica 6.1" (licensed № AXX910A374605FA). The obtained data testify to the fact that the syndrome of emotional burnout is most often observed among pupils at the aged 15 and 17, and in terms of age and sex, mainly among young men compared to young women. The differences between the rates of young women and young men are probably to be explained by their greater emotional openness and greater resistance of the organism to the action of stressors in comparison with young men. On the other hand, high levels of emotional burnout among young men compared to young women testify to their inability to spend their emotions economically, to effectively resist the actions of traumatic environmental factors and social living conditions. It is determined that the level of emotional burnout of schoolchildren is high among young women - due to the high level of expression of the phase of resistance, which indicates the development of resistance to emotional stress, among young men - due to phases of stress and exhaustion, which indicates significant depletion of adaptation mechanisms. The identified trends determine the need to develop conceptual frameworks for overcoming the leading manifestations of emotional burnout, which involve the use of personality-oriented approaches to improve the individual's ability to cope with stress due to changing stereotypes of their own behavior, relationships and relationships with others. mastering stress management skills, learning relaxation techniques, introduction of psychohygienic correction measures to pupils' daily activities.

Keywords: pupils, modern school, emotional burnout, dynamic changes.
\end{abstract}

\section{Introduction}

According to the World Health Organization, burnout syndrome is a state of physical, motivational and, above all, emotional exhaustion, which is characterized by decreased and other disorders of productivity/training, the presence of severe fatigue, insomnia and increased tendency to form against this background of somatic diseases, as well as the use of psychoactive substances in order to obtain temporary relief, which has a pronounced tendency to develop psychological or physiological dependence and manifestations of suicidal behavior [5, 6, 
14, 21].

In fact, this syndrome and, of course, its main criteria, should be regarded as a stress response to too high professional, educational or emotionally significant requirements, which is realized due to excessive devotion to human work with concomitant (which should be emphasized!) to rest, family life and rational organization of free time [5, 9, 17].

That is why it is extremely important to use modern psychodiagnostic techniques and psychohygienic techniques to determine the level of emotional burnout. In this context, it should be noted that a thorough assessment of psychophysiological functions and personality traits inherent in different contingents, in particular for pupils and students should aim to determine in detail the functional mechanisms of occurrence and features of the combination of major structural components of emotional burnout. This approach allows the subject to pay timely attention to the depth of expression of the leading manifestations of emotional burnout and, if necessary, to mobilize internal resources, apply preventive (especially psychophysiological and, especially, psychohygienic) methods, to study themselves, to continue, despite existing problems, personal and professional development [1, 3, $4,15,18,19,23,26,27]$.

The purpose of the work is to determine the leading indicators of emotional burnout of pupils aged 15-17 years and to establish the features of their dynamic changes during education in a modern school.

\section{Materials and methods}

The research was conducted on the basis of a number of secondary education institutions located in Vinnytsia, during which 309 pupils (158 young women and 151 young men) aged 15 to 17 were supervised.

To determine and subsequently assess the indicators of emotional burnout was used extremely common in psychohygienic research and psychodiagnostic practices Boyko's personal questionnaire, which provided an opportunity to identify 12 symptoms that form 3 phases of emotional burnout: stress phase, resistance phase and exhaustion phase. In this context, it should be noted that the structure of the stress phase includes symptoms of traumatic circumstances, self-dissatisfaction, feelings of "cage", anxiety and depression, the structure of the resistance phase - symptoms of inadequate selective emotional response, emotional and moral disorientation, expansion emotions and reduction of professional responsibilities, to the structure of the phase of exhaustion - symptoms of emotional deficit, emotional and personal detachment, as well as psychosomatic and psychovegetative disorders [15, 21, 24, 25].

In addition, for each of the identified symptoms, there are 3 stages of development - a symptom that is unformed (up to 9 points), a symptom that is forming (10-15 points), and a symptom that has formed (more than 16 points).
Accordingly, each phase of the development of emotional burnout is defined as one that is unformed (up to 37 points for the set of symptoms that make it up), one that is forming (37-60 points for the set of symptoms that make it up), and one that is formed (more than 60 points for the set of symptoms that make it up).

Statistical analysis of the obtained data, which involved the application of descriptive statistics procedures, was carried out on the basis of the use of a standard package of multidimensional statistical analysis applications "Statistica 6.1" (licensed № AXX910A374605FA).

\section{Results}

During the assessment of the degree of expression of the total indicator of emotional burnout, which is an extremely important integral indicator of emotional instability and propensity to develop and form various disorders of the mental sphere, quite interesting results were obtained.

In general, the level of emotional burnout was the highest among young men aged 15 and 17 years (respectively $164.7 \pm 7.6$ and $151.3 \pm 9.0$ points $(8.1 \% ; p>0.05))$ compared with young men aged 16 years (147.5 \pm 8.8 points) $10.4 \%$; $p>0.05)$ ). At the same time, the rates among young women were much lower, however, in the age context the same trend was maintained as among young men, and, therefore, the level of emotional burnout was lowest among young women aged 16 compared to young women aged 15 and 17 (respectively - $125.6 \pm 7.5$ points $(15.9 \% ; p<0.05)$; $149.3 \pm 7.8$ points and $148.0 \pm 7.0$ points $(0.9 \% ; p>0.05)$ ). No statistically significant sex differences were observed (p>0.05) (Table 1).

The first phase of the development of emotional burnout is characterized by the appearance of manifestations of exhaustion of their own emotional resources and a feeling of constant tension. The indicators that characterized the stress phase in young men were higher than in young women. Among the pupils studied, only among 16-yearold and 17-year-old young women, stress was defined as an unformed phase, while in other comparison groups it should be interpreted as a developing stage. Thus, at the age of 15 among young women the level of stress was the highest $-40.76 \pm 3.16$ points, however, at the age of 16 and 17 its values were respectively $29.66 \pm 3.07$ points $(27.2 \%$, $\mathrm{p}<0.05)$ and $32.81 \pm 3.25$ points $(19.5 \% ; \mathrm{p}>0.05)$. Among young men, the level of stress clearly depended on age and gradually decreased, amounting to $45.70 \pm 2.92$ points at the age of $15,42.46 \pm 3.50$ points at the age of $16(7.1 \%$; $p>0.05)$ and $42.88 \pm 3.75$ points at the age of $17(6.2 \%$, $p>0.05)$.

In the analysis of structural indicators, it was also necessary to pay attention to the presence of trends that are clearly due to sex differences. As an emerging stage, stress should be treated among $23.5 \%$ of young men aged 15 , among $28.0 \%$ of young men aged 16 and among $36.0 \%$ of young men aged 17 , which indicates an increase 
Table 1. Indicators of the level of emotional burnout of pupils according to the Boyko's personal questionnaire in the dynamics of learning, scores.

\begin{tabular}{|c|c|c|c|c|c|c|}
\hline \multirow{3}{*}{$\begin{array}{l}\text { Indicators of } \\
\text { emotional } \\
\text { bumout }\end{array}$} & \multirow{3}{*}{$\begin{array}{c}\text { Research } \\
\text { period }\end{array}$} & \multicolumn{4}{|c|}{ Groups of pupils } & \multirow{3}{*}{$P_{g-b}$} \\
\hline & & \multicolumn{2}{|c|}{ young women } & \multicolumn{2}{|c|}{ young men } & \\
\hline & & $\mathrm{n}$ & $\mathrm{M} \pm \mathrm{m}$ & $\mathrm{n}$ & $\mathrm{M} \pm \mathrm{m}$ & \\
\hline \multirow{6}{*}{$\begin{array}{l}\text { Total indicator } \\
\text { of emotional } \\
\text { burnout }\end{array}$} & 15 years & 52 & $149.3 \pm 7.8$ & 51 & $164.7 \pm 7.6$ & $>0.05$ \\
\hline & 16 years & 53 & $125.6 \pm 7.5$ & 50 & $147.5 \pm 8.8$ & $>0.05$ \\
\hline & 17 years & 53 & $148.0 \pm 7.0$ & 50 & $151.2 \pm 9.0$ & $>0.05$ \\
\hline & $p_{15-16}$ & \multicolumn{2}{|r|}{$<0.05$} & \multicolumn{2}{|r|}{$>0.05$} & \\
\hline & $p_{16-17}$ & \multicolumn{2}{|r|}{$<0.05$} & \multicolumn{2}{|r|}{$>0.05$} & \\
\hline & $p_{15-17}$ & \multicolumn{2}{|r|}{$>0.05$} & \multicolumn{2}{|r|}{$>0.05$} & \\
\hline \multirow{6}{*}{ Intensity } & 15 years & 52 & $40.76 \pm 3.16$ & 51 & $45.70 \pm 2.92$ & $>0.05$ \\
\hline & 16 years & 53 & $29.66 \pm 3.07$ & 50 & $42.46 \pm 3.50$ & $<0.01$ \\
\hline & 17 years & 53 & $32.81 \pm 3.25$ & 50 & $42.88 \pm 3.75$ & $<0.05$ \\
\hline & $p_{15-16}$ & & $<0.05$ & \multicolumn{2}{|r|}{$>0.05$} & \\
\hline & $p_{16-17}$ & & $>0.05$ & \multicolumn{2}{|r|}{$>0.05$} & \\
\hline & $\mathrm{p}_{15-17}$ & \multicolumn{2}{|r|}{$>0.05$} & \multicolumn{2}{|r|}{$>0.05$} & \\
\hline \multirow{6}{*}{$\begin{array}{l}\text { Experiencing } \\
\text { psycho- } \\
\text { traumatic } \\
\text { circumstances }\end{array}$} & 15 years & 52 & $12.94 \pm 1.07$ & 51 & $12.52 \pm 0.99$ & $>0.05$ \\
\hline & 16 years & 53 & $8.282 \pm 1.184$ & 50 & $11.62 \pm 1.16$ & $<0.05$ \\
\hline & 17 years & 53 & $9.641 \pm 1.012$ & 50 & $11.52 \pm 1.13$ & $>0.05$ \\
\hline & $p_{15-16}$ & & $<0.01$ & \multicolumn{2}{|r|}{$>0.05$} & \\
\hline & $p_{16-17}$ & \multicolumn{2}{|r|}{$>0.05$} & \multicolumn{2}{|r|}{$>0.05$} & \\
\hline & $p_{15-17}$ & \multicolumn{2}{|r|}{$<0.05$} & & $>0.05$ & \\
\hline & 15 years & 52 & $8.154 \pm 0.776$ & 51 & $9.092 \pm 0.872$ & $>0.05$ \\
\hline & 16 years & 53 & $7.154 \pm 0.792$ & 50 & $9.960 \pm 1.015$ & $<0.05$ \\
\hline Diss & 17 years & 53 & $6.621 \pm 0.554$ & 50 & $10.26 \pm 0.99$ & $<0.01$ \\
\hline & $p_{15-16}$ & & $>0.05$ & & $>0.05$ & \\
\hline & $p_{16-17}$ & & $>0.05$ & & $>0.05$ & \\
\hline & $p_{15-17}$ & & $>0.05$ & & $>0.05$ & \\
\hline & 15 years & 52 & $7.803 \pm 1.032$ & 51 & $10.23 \pm 0.92$ & $>0.05$ \\
\hline & 16 years & 53 & $6.030 \pm 0.891$ & 50 & $8.801 \pm 1.034$ & $<0.05$ \\
\hline & 17 years & 53 & $6.134 \pm 1.135$ & 50 & $10.08 \pm 1.28$ & $<0.05$ \\
\hline bein & $p_{15-16}$ & & $>0.05$ & & $>0.05$ & \\
\hline & $p_{16-17}$ & & $>0.05$ & & $>0.05$ & \\
\hline & $p_{15-17}$ & & $>0.05$ & & $>0.05$ & \\
\hline & 15 years & 52 & $11.86 \pm 1.28$ & 51 & $13.84 \pm 1.16$ & $>0.05$ \\
\hline & 16 years & 53 & $8.155 \pm 1.183$ & 50 & $11.46 \pm 1.31$ & $>0.05$ \\
\hline & 17 years & 53 & $10.41 \pm 1.20$ & 50 & $11.02 \pm 1.42$ & $>0.05$ \\
\hline depression & $p_{15-16}$ & & $<0.05$ & & $>0.05$ & \\
\hline & $p_{16-17}$ & & $>0.05$ & & $>0.05$ & \\
\hline & $p_{15-17}$ & & $>0.05$ & & $>0.05$ & \\
\hline & 15 years & 52 & $60.88 \pm 2.90$ & 51 & $58.58 \pm 2.74$ & $>0.05$ \\
\hline & 16 years & 53 & $52.11 \pm 2.50$ & 50 & $51.82 \pm 2.72$ & $>0.05$ \\
\hline & 17 years & 53 & $64.00 \pm 2.45$ & 50 & $55.20 \pm 2.76$ & $<0.05$ \\
\hline resistance & $p_{15.16}$ & & $<0.05$ & & $>0.05$ & \\
\hline & $p_{16.17}$ & & $<0.001$ & & $>0.05$ & \\
\hline & $p_{15-17}$ & & $>0.05$ & & $>0.05$ & \\
\hline
\end{tabular}

in the values of its characteristics with age. Young women had a tendency to reverse the content. The formed level of

\section{Continuation of table 1.}

\begin{tabular}{|c|c|c|c|c|c|c|}
\hline \multirow{3}{*}{$\begin{array}{l}\text { Indicators of } \\
\text { emotional } \\
\text { burnout }\end{array}$} & \multirow{3}{*}{$\begin{array}{l}\text { Research } \\
\text { period }\end{array}$} & \multicolumn{4}{|c|}{ Groups of pupils } & \multirow{3}{*}{$P_{g-b}$} \\
\hline & & \multicolumn{2}{|c|}{ young women } & \multicolumn{2}{|c|}{ young men } & \\
\hline & & $n$ & $\mathrm{M} \pm \mathrm{m}$ & $n$ & $\mathrm{M} \pm \mathrm{m}$ & \\
\hline \multirow{6}{*}{$\begin{array}{l}\text { Inadequate } \\
\text { selective } \\
\text { emotional } \\
\text { response }\end{array}$} & 15 years & 52 & $19.76 \pm 0.96$ & 51 & $17.35 \pm 0.92$ & $>0.05$ \\
\hline & 16 years & 53 & $18.62 \pm 0.95$ & 50 & $15.66 \pm 0.95$ & $<0.05$ \\
\hline & 17 years & 53 & $21.30 \pm 0.75$ & 50 & $17.96 \pm 1.01$ & $<0.01$ \\
\hline & $p_{15-16}$ & \multicolumn{2}{|r|}{$>0.05$} & \multicolumn{2}{|r|}{$>0.05$} & \\
\hline & $p_{16-17}$ & \multicolumn{2}{|r|}{$<0.05$} & \multicolumn{2}{|r|}{$>0.05$} & \\
\hline & $p_{15-17}$ & \multicolumn{2}{|r|}{$>0.05$} & \multicolumn{2}{|r|}{$>0.05$} & \\
\hline \multirow{6}{*}{$\begin{array}{c}\text { Emotional and } \\
\text { moral } \\
\text { disorientation }\end{array}$} & 15 years & 52 & $12.36 \pm 0.90$ & 51 & $13.62 \pm 0.94$ & $>0.05$ \\
\hline & 16 years & 53 & $11.07 \pm 0.91$ & 50 & $12.44 \pm 0.88$ & $>0.05$ \\
\hline & 17 years & 53 & $11.90 \pm 0.93$ & 50 & $12.92 \pm 0.87$ & $>0.05$ \\
\hline & $p_{15-16}$ & \multicolumn{2}{|r|}{$>0.05$} & \multicolumn{2}{|r|}{$>0.05$} & \\
\hline & $p_{16-17}$ & \multicolumn{2}{|r|}{$>0.05$} & \multicolumn{2}{|r|}{$>0.05$} & \\
\hline & $p_{15-17}$ & \multicolumn{2}{|r|}{$>0.05$} & \multicolumn{2}{|r|}{$>0.05$} & \\
\hline \multirow{6}{*}{$\begin{array}{l}\text { Expanding the } \\
\text { scope of } \\
\text { saving } \\
\text { emotions }\end{array}$} & 15 years & 52 & $13.32 \pm 1.24$ & 51 & $12,66 \pm 1,14$ & $>0.05$ \\
\hline & 16 years & 53 & $8.791 \pm 0.993$ & 50 & $10,66 \pm 1,30$ & $>0.05$ \\
\hline & 17 years & 53 & $13.67 \pm 1.24$ & 50 & $11,34 \pm 1,25$ & $>0.05$ \\
\hline & $p_{15-16}$ & \multicolumn{2}{|r|}{$<0.01$} & \multicolumn{2}{|r|}{$>0.05$} & \\
\hline & $p_{16-17}$ & & $<0.01$ & & $>0.05$ & \\
\hline & $p_{15-17}$ & & $>0.05$ & & $>0.05$ & \\
\hline & 15 years & 52 & $15.42 \pm 1.16$ & 51 & $15.00 \pm 1.10$ & $>0.05$ \\
\hline & 16 years & 53 & $14.05 \pm 0.95$ & 50 & $12.42 \pm 0.98$ & $>0.05$ \\
\hline Reduction of & 17 years & 53 & $17.11 \pm 0.99$ & 50 & $12.98 \pm 1.16$ & $<0.01$ \\
\hline responsibilities & $p_{15-16}$ & & $>0.05$ & & $>0.05$ & \\
\hline & $p_{16-17}$ & & $<0.05$ & & $>0.05$ & \\
\hline & $p_{15-17}$ & & $>0.05$ & & $>0.05$ & \\
\hline & 15 years & 52 & $47.67 \pm 3.01$ & 51 & $60.29 \pm 2.96$ & $<0.01$ \\
\hline & 16 years & 53 & $43.24 \pm 2.92$ & 50 & $53.92 \pm 3.71$ & $<0.05$ \\
\hline Level of & 17 years & 53 & $51.23 \pm 2.70$ & 50 & $53.26 \pm 3.50$ & $>0.05$ \\
\hline "exhaustion" & $p_{15-16}$ & & $>0.05$ & & $>0.05$ & \\
\hline & $p_{16-17}$ & & $<0.05$ & & $>0.05$ & \\
\hline & $p_{15-17}$ & & $>0.05$ & & $>0.05$ & \\
\hline & 15 years & 52 & $10.40 \pm 1.03$ & 51 & $13.94 \pm 0.82$ & $<0.01$ \\
\hline & 16 years & 53 & $11.24 \pm 0.97$ & 50 & $11.66 \pm 1.01$ & $>0.05$ \\
\hline Emotional & 17 years & 53 & $12.15 \pm 1.01$ & 50 & $10.92 \pm 1.04$ & $>0.05$ \\
\hline & $p_{15-16}$ & & $>0.05$ & & $>0.05$ & \\
\hline & $p_{16-17}$ & & $>0.05$ & & $>0.05$ & \\
\hline & $p_{15-17}$ & & $>0.05$ & & $<0.05$ & \\
\hline & 15 years & 52 & $14.42 \pm 0.99$ & 51 & $19.16 \pm 0.98$ & $<0.001$ \\
\hline & 16 years & 53 & $14.96 \pm 0.92$ & 50 & $18.26 \pm 1.03$ & $<0.05$ \\
\hline The level of & 17 years & 53 & $16.19 \pm 0.99$ & 50 & $18.02 \pm 0.81$ & $>0.05$ \\
\hline detachment & $p_{15-16}$ & & $>0.05$ & & $>0.05$ & \\
\hline & $p_{16-17}$ & & $>0.05$ & & $>0.05$ & \\
\hline & $p_{15-17}$ & & $>0.05$ & & $>0.05$ & \\
\hline
\end{tabular}

tension was registered in $23.1 \%$ of 15 -year-old young women, in $15.1 \%$ of 16 -year-old young women and in $11.3 \%$ of 17 -year-old young women. 


\section{Continuation of table 1.}

\begin{tabular}{|c|c|c|c|c|c|c|}
\hline \multirow{3}{*}{$\begin{array}{c}\text { Indicators of } \\
\text { emotional } \\
\text { burnout }\end{array}$} & \multirow{3}{*}{$\begin{array}{c}\text { Research } \\
\text { period }\end{array}$} & \multicolumn{4}{|c|}{ Groups of pupils } & \multirow{3}{*}{$P_{g-b}$} \\
\hline & & \multicolumn{2}{|c|}{ young women } & \multicolumn{2}{|r|}{ young men } & \\
\hline & & $\mathrm{n}$ & $\mathrm{M} \pm \mathrm{m}$ & $\mathrm{n}$ & $\mathrm{M} \pm \mathrm{m}$ & \\
\hline \multirow{6}{*}{$\begin{array}{l}\text { The level of } \\
\text { personal } \\
\text { detachment }\end{array}$} & 15 years & 52 & $13.92 \pm 1.33$ & 51 & $16.55 \pm 1.24$ & $>0.05$ \\
\hline & 16 years & 53 & $11.00 \pm 1.18$ & 50 & $14.48 \pm 1.48$ & $<0.05$ \\
\hline & 17 years & 53 & $14.62 \pm 0.31$ & 50 & $15.92 \pm 1.51$ & $>0.05$ \\
\hline & $p_{15-16}$ & \multicolumn{2}{|r|}{$>0.05$} & \multicolumn{2}{|r|}{$>0.05$} & \\
\hline & $\mathrm{p}_{16-17}$ & \multicolumn{2}{|r|}{$<0.05$} & \multicolumn{2}{|r|}{$>0.05$} & \\
\hline & $\mathrm{p}_{15-17}$ & \multicolumn{2}{|r|}{$>0.05$} & \multicolumn{2}{|r|}{$>0.05$} & \\
\hline \multirow{6}{*}{$\begin{array}{l}\text { The level of } \\
\text { expression of } \\
\text { psychosomatic } \\
\text { and psycho- } \\
\text { vegetative } \\
\text { changes }\end{array}$} & 15 years & 52 & $9.116 \pm 1.062$ & 51 & $10.60 \pm 0.99$ & $>0.05$ \\
\hline & 16 years & 53 & $6.754 \pm 0.813$ & 50 & $9.521 \pm 1.274$ & $>0.05$ \\
\hline & 17 years & 53 & $8.261 \pm 0.951$ & 50 & $8.202 \pm 1.112$ & $>0.05$ \\
\hline & $p_{15-16}$ & & $>0.05$ & & $>0.05$ & \\
\hline & $p_{16-17}$ & & $>0.05$ & & $>0.05$ & \\
\hline & $\mathrm{p}_{15-17}$ & & $>0.05$ & & $>0.05$ & \\
\hline
\end{tabular}

During the analysis of the peculiarities of the development of signs that are characteristic of the stress phase, it was found that the symptoms of traumatic circumstances should be defined as unformed in young women aged 16 and 17 years, as well as emerging symptoms in other comparison groups. Thus, among the 15-year-old young women the indicator under consideration was significantly higher, amounting to $12.94 \pm 1.08$ points in comparison with young women aged 16 and 17 (8.282 \pm 1.184 points $(36.0 \% ; p<0.01)$ and $9.641 \pm 1.012$ points respectively $(25.5 \% ; \mathrm{p}<0.05))$. Among young men, the indicators gradually decreased with age from $12.52 \pm 0.99$ points at the age of 15 to $11.62 \pm 1.16$ points $(7.2 \% ; p>0.05)$ at the age of 16 and $11.52 \pm 1.13$ points $(8.0 \% ; p>0.05)$ at the age of 17 . Significant sex differences were registered only among 16 -year-old schoolchildren $(p<0.05)$.

The symptom of feeling "in a cage" was registered as unformed in young women, among whom its level decreased from $7.803 \pm 1.032$ points in 15 years to $6.030 \pm 0.891$ points in 16 years $(22.7 \% ; p>0.05)$ and slightly increased to $6.134 \pm 1.135$ points at 17 years $(21.4 \%$; $\mathrm{p}>0.05)$, as well as among 16-year-olds - 8.801 \pm 1.034 points (14.0\%; p>0.05). At the same time, among 15-yearold and 17-year-old young men, the feeling of "being trapped in a cage" was defined as a developing symptom $(10.23 \pm 0.92$ points and $10.08 \pm 1.28$ points, respectively $(1.5 \% ; p>0.05))$. Significant sex differences were registered among 16-year-old pupils $(p<0.05)$.

A similar trend was characteristic of the indicators of self-dissatisfaction, which in young women should be interpreted as unformed, and its level decreased with age from $8.154 \pm 0.776$ points to $6.621 \pm 0.554$ points $(18.8 \%$; $\mathrm{p}>0.05)$. In contrast, in young men, the symptom was defined as developing, increasing with age from $9.092 \pm 0.872$ points to $10.26 \pm 0.99$ points $(12.9 \% ; p>0.05)$. Significant sex differences were observed among 16-year- olds $(p<0.05)$ and 17-year-old schoolchildren $(p<0.01)$.

The symptom of anxiety and depression, among all the symptoms that form the stage of stress, was the only one, which was determined in all sex and all age groups at approximately the same level, ranging from $10.41 \pm 1.20$ points in 17-year-old young women to $13.84 \pm 1.16$ points in 15-year-old young men, except for 16-year-old young women, among whom its manifestations (8.155 \pm 1.183 points) should be interpreted as a developing symptom.

Of the three main components of emotional burnout among the studied pupils, the highest was the level of resistance, which corresponds to the second phase of the formation of emotional burnout and indicates the development of their body's natural resistance to emotional stress. In young women, the level of resistance was higher than in young men, among young women aged 15 and 17 years resistance was a stage that was formed, and accordingly its indicators increased from $60.88 \pm 2.91$ to $64.00 \pm 2.45$ points $(5.1 \%$; $>0.05)$, in other groups of comparison - as a developing stage, and the lowest level of resistance was among pupils aged 16 years. In particular, among young women aged 16 its level was $52.11 \pm 2.50$ points $(14.4 \% ; p<0.05)$, among young men aged 15 years resistance was determined at the level of $58.58 \pm 2.74$ points, at the age of 16 years $-51.82 \pm 2.72$ points $(11.5 \% ; p>0.05)$, at the age of 17 years $-55.20 \pm 2.76$ points $(5.8 \% ; p>0.05)$. Significant sex differences were observed only among 17year-old schoolchildren $(p<0.05)$.

The structure of the studied indicators was dominated by the values that were inherent in the formed phase. In general, among 15-year-old pupils, the resistance stage was fully formed among $48.1 \%$ of young women and $49.0 \%$ of young men. The lowest rates were among schoolchildren aged 16 - among $34.0 \%$ of young women and $26.0 \%$ of young men. Among young women aged 17 , the resistance stage was fully formed in $64.2 \%$ of respondents, which is a fairly high figure, which cannot help but cause concern. On the other hand, among young men aged 17, the resistance stage was formed only in $38.0 \%$ of cases.

Among the main mental manifestations that are part of the resistance phase, inadequate selective emotional response to environmental influences was defined as a symptom in all comparison groups except 16-year-old young men. The lowest degree of expression of this symptom among young women was at the age of 16 years - $18.62 \pm 0.95$ points $(5.8 \%, p>0.05)$. Slightly higher levels were observed among 15-year-old and 17-year-old young women, accounting for $19.76 \pm 0.96$ and $21.30 \pm 0.75$ points, respectively $(7.8 \%, \mathrm{p}<0.05)$. Among young men aged 15 and 17 , the levels of inadequate selective emotional response did not differ significantly and amounted to $17.35 \pm 0.92$ points and $17.96 \pm 1.01$ points, respectively (3.5\%, p>0.05), a significantly lower level was found among 16 -year-old young men, $15.66 \pm 0.95$ points $(9.7 \%, p>0.05)$. Significant sex differences were registered among pupils 
aged $16(p<0.05)$ and aged $17(p<0.01)$

Other symptoms inherent in the manifestations of emotional burnout were determined at the stage of formation, in addition to the symptom of expanding the scope of saving emotions, which among young women at the age of 16 was unformed. There were almost identical trends in the age and sex dynamics of the levels of expansion of the economy of emotion saving and reduction of professional responsibilities - the lowest levels were for 16-year-olds and were determined primarily among young men, the highest levels were for young women and young men aged 15 years. Thus, the level of expansion of the sphere of saving emotions ranged from $13.32 \pm 1.24$ points among 15 -year-old young women to $8.791 \pm 0.993$ points (34.0\%; $p<0.01$ ) among 16-year-old young women and up to $13.67 \pm 1.24$ points $(2.6 \% ; p>0.05)$ among 17 -year-old young women and from $12.66 \pm 1.14$ points among 15 -yearold young men to $10.66 \pm 1.30$ points $(15.8 \%$; $p>0.05$ ) among 16-year-old young men and up to $11.34 \pm 1.25$ points (10.4\%; p>0.05) among 17-year-old young men, the level of reduction of professional responsibilities - respectively from $15.42 \pm 1.16$ points among 15-year-old young women up to $14.05 \pm 0.95$ points $(8.9 \% ; p>0.05)$ among 16 -yearold young women and up to $17.11 \pm 0.99$ points $(11.0 \%$; $p>0.05$ ) among 17-year-old young women and from $15.00 \pm 1.10$ points among 15-year-old young men up to $12.42 \pm 0.98$ points $(17.2 \% ; p>0.05)$ among 16 -year-old young men and up to $12.98 \pm 1.16$ points $(13.5 \%$; $p>0.05)$ among 17-year-old young men. Significant sex differences were observed among 17-year-old pupils $(p<0.01)$.

Against this background, the fact that the level of emotional and moral disorientation, in contrast to the previously described symptoms, was much higher among young men compared to young women should be considered very noticeable. Thus, if among young women the value of the studied symptom varied in the range from $12.36 \pm 0.90$ points among female pupils aged 15 years to $11.07 \pm 0.91$ points $(10.4 \% ; p>0.05)$ among young women aged 16 years and up to $11.90 \pm 0.93$ points; $p>0.05$ ) among young women aged 17 years, among young men its values ranged from $13.62 \pm 0.94$ points to $12.44 \pm 0.88$ points $(8.7 \% ; p>0.05)$ and to $12.92 \pm 0.87$ points, respectively $(5.1 \% ; p>0.05)$. Regarding the number of schoolchildren, among whom there were symptoms of emotional and moral disorientation, the same trend was observed as when assessing the phase of resistance in general. The highest rates were among young women aged 17 years, the lowest - among young men aged 15 years. These data indicate a much more pronounced tendency of young women to resist emotional exhaustion, especially at the age of 17 , compared with their peers young men.

The third stage of development of emotional burnout, characterized by depletion of adaptive mechanisms, as formed was recorded among young men aged 15 years $(60.29 \pm 2.96$ points) and as a developing stage in other age groups. Among young men, the level of exhaustion decreased with age to $53.92 \pm 3.71$ points $(10.6 \%$; $p>0.05)$ at the age of 16 to $53.26 \pm 3.50$ points $(11.7 \% ; p>0.05)$ at the age of 17 years and, in general, was higher than the level of exhaustion in young women, which, in turn, with age initially decreased from $47.67 \pm 3.01$ at the age of 15 years to $43.24 \pm 2.92$ points $(9.3 \% ; p>0.05)$ at the age of 16 years, increasing further to $51.23 \pm 2.70$ points $(7.5 \%$; $p>0.05)$. Expressed sex-related differences were registered at the age of 15 years $(p<0.01)$ and at the age of 16 years $(p<0.05)$.

As a formed stage of exhaustion was registered among $51.0 \%$ of young men aged 15 years, among $42.0 \%$ of young men aged 16 years and among $44.0 \%$ of young men aged 17 years, which is significantly higher than for young women, among whom similar data were respectively $30.8 \%, 22.6 \%$ and $32.1 \%$.

Among the symptoms that are integral components of the depletion phase, the lowest was the level of expression of psychosomatic and psychovegetative changes, which decreased during the studied age in range from $9.116 \pm 1.062$ up to $8.261 \pm 0.951$ points $(9.3 \% ; p>0.05)$ for young women and from $10.60 \pm 0.99$ to $8.202 \pm 1.112$ points $(22.6 \% ; p>0.05)$ in young men. No sex differences were observed ( $p>0.05)$.

Emotional deficit was defined as a developing symptom in all comparison groups and, in contrast to the symptom of psychosomatic and psychovegetative changes, among young women its level increased with age from $10.40 \pm 1.04$ to $12.15 \pm 1.01$ points $(16.8 \% ; p>0.05)$, among young men, on the contrary, decreased from $13.94 \pm 0.82$ to $10.92 \pm 1.04$ points $(21.7 \% ; p<0.05)$. Sex-related differences were registered only among 15 -year-old schoolchildren $(p<0.01)$.

The levels of emotional and personal detachment were quite high. The level of emotional detachment was defined as a symptom that developed in all comparison groups, except for young women aged 15 and 16 years. Among young women the level of indicators with age increased from $14.42 \pm 0.99$ to $16.19 \pm 0.99$ points $(12.3 \%$; $p>0.05$ ), among young men, instead, decreased from $19.16 \pm 0.98$ to $18.02 \pm 0.91$ points $(5.9 \% ; p>0.05)$. The symptom of personal withdrawal was registered as a developing symptom and decreased over the age period from $13.92 \pm 1.33$ among 15 -year-old young women to $11.00 \pm 1.18$ points $(21.0 \%$; p $>0.05)$ among 16 -year-old young women, increasing to $14.62 \pm 0.31$ points $(5.0 \%$; $\mathrm{p}>0.05$ ) among 17 -year-old young women, and decreased from $16.55 \pm 1.24$ points among 15-year-old young men to $14.48 \pm 1.48$ points $(12.5 \% ; p>0.05)$ among 16 -year-old young men, increasing to $15.92 \pm 1.51$ points $(3.8 \% ; p>0.05)$ among 17-year-old young men.

\section{Discussion}

Analysis of the data of modern scientific literature and own results convincingly proves the fact that in the structure of personality traits of modern pupils an important place belongs to the leading characteristics of the level of 
emotional burnout, which is an indisputable factor in forming a high level of emotional instability of young women and young men to the action of environmental factors and social and professional living conditions, as well as the tendency to develop various disorders of the characteristics of the psycho-emotional sphere of their body due to the influence of various psycho-traumatic factors [2, 5, 14, 23, 24, 25].

Moreover, emotional burnout is a kind of anxietydepressive or purely depressive reaction that occurs without any trauma, without any functional or organic disorders [7, $8,10,13,15,16]$.

In general, in the structure of emotional burnout, primarily professional or educational-conditioned emotional burnout, it is customary to distinguish the following levelscomponents: (1) emotional exhaustion, which manifests itself as mental fatigue, emotional devastation, depressive manifestations; (2) reduction of personal achievements, which is marked as a decrease in educational or professional efficiency of students or employees, negativism about the proper performance of official duties, reduced sense of significance of activities performed, etc. and (3) depersonalization, ie significant interpersonal relationships, cynical attitude to the feelings and experiences of other people [5, 11, 12, 16, 20, 22].

The obtained data convincingly testify to the fact that the manifestations of emotional burnout, in fact, at all levels, which are listed above, are most often observed among pupils aged 15 and 17 years. In addition, considering them in the sex-age plane, it is necessary to note a higher degree of their expression among young men compared to young women. This situation is probably to be explained by the much greater emotional openness of young women and the greater resistance of their bodies to the action of stressors compared to young men. At the same time, rather high levels of emotional burnout among young men compared to young women testified to the inability of the stronger sex to spend their emotions quite sparingly, to effectively confront the action of various traumatic environmental factors and social living conditions, which often leads to greater emotional "stinginess" of men compared to women.

It is interesting to note that the level of emotional burnout of high school pupils was too high: in young women - due to the high level of expression of the resistance phase, which indicates the development of resistance to emotional stress, in young men - due to phases of stress and

\section{References}

[1] Aherne, D., Farrant, K., Hickey, L., Hickey, E., McGrath, L., \& McGrath, D. (2016). Mindfulness based stress reduction for medical students: optimising student satisfaction and engagement. BMC medical education, 16(1), 1-11. doi: 10.1186/ s12909-016-0728-8

[2] Al Rasheed, F., Naqvi, A. A., Ahmad, R., \& Ahmad, N. (2017). Academic stress and prevalence of stress-related selfmedication among undergraduate female students of health exhaustion. which indicates a significant depletion of adaptation mechanisms.

This situation determines the need to develop conceptual frameworks for overcoming the leading manifestations of emotional burnout, which involve the use of personality-oriented approaches aimed at improving the individual's ability to cope with stress due to changing stereotypes of their own behavior, relationships. Instead, the main components of such approaches should be considered the mastery and proper acquisition of stress management skills; training in relaxation techniques, introduction of psycho-hygienic correction measures to pupils' daily activities, etc.

\section{Conclusions}

1. These data indicate the fact that the syndrome of emotional burnout is most common among pupils aged 15 and 17 years, as well as in terms of age and sex among young men compared to young women. The difference between the rates in young women and young men is probably due to their greater emotional openness and greater resistance to stressors compared to young women. On the other hand, high levels of emotional burnout among young men compared to young women indicate their inability to expend their emotions economically, effectively resist the effects of traumatic environmental factors and social living conditions, which in turn leads to greater emotional "stinginess" of men compared to women.

2. Studies have shown that the level of emotional burnout of schoolchildren is too high - among young women due to the high level of expression of the phase of resistance, which indicates the development of resistance to emotional stress, among young men - due to phases of stress and exhaustion, indicating significant exhaustion, which indicates a significant depletion of adaptation mechanisms.

3. The identified trends determine the need to develop conceptual frameworks for overcoming the leading manifestations of emotional burnout, which involve the use of personality-oriented approaches aimed at improving the individual's ability to cope with stress due to changing stereotypes of their behavior, relationships with others, the main components of which should be considered the mastery and proper mastery of stress management skills; training in relaxation techniques, introduction of psychohygienic correction measures into the structure of students' daily activities.

and non-health cluster colleges of a public sector university in Dammam, Saudi Arabia. Journal of pharmacy \& bioallied sciences, 9(4), 251-258. doi: 10.4103/jpbs.JPBS_189_17

[3] Backović, D. V., llić Živojinović, J., Maksimović, J., \& Maksimović, M. (2012). Gender differences in academic stress and burnout among medical students in final years of education. Psychiatria Danubina, 24(2), 175-181. PMID: 22706416

[4] Bedewy, D., \& Gabriel, A. (2013). The Development and 
Psychometric Assessment of a Scale to Measure the Severity of Examination Anxiety among Undergraduate University Students. International journal of educational psychology, 2(1), 81-104. doi: 10.4471/ijep.2013.19

[5] Bodrov, V. А. (2006). Психология профессиональной деятельности. Теоретические и практические проблемы [Psychology of professional activity. Theoretical and applied problems]. Москва: Издательство "Институт психологии PAH" - Moscow: Publishing house "Institute of Psychology RAS".

[6] Gorter, R. C. (2001). Burnout among dentists: a question of coping. Nederlands tijdschrift voor tandheelkunde, 108(11), 458-461. PMID: 11732139

[7] Hagger, M. S., \& Chatzisarantis, N. L. (2011). Causality orientations moderate the undermining effect of rewards on intrinsic motivation. Journal of Experimental Social Psychology, 47(2), 485-489. doi: 10.1016/j.jesp.2010.10.010

[8] Higuchi, D., \& Echigo, A. (2016). Characteristics of coping strategies and the relationships between coping strategies and stress reactions in physical therapy students during clinical practice. Journal of physical therapy science, 28(10), 2867-2870. doi: 10.1589/jpts.28.2867

[9] Hodkinson, P. (2016). Youth cultures and the rest of life: Subcultures, post-subcultures and beyond. Journal of Youth Studies, 19(5), 629-645. doi: 10.1080/ 13676261.2015 .1098778

[10] K?tter, T., \& Niebuhr, F. (2016). Resource-oriented coaching for reduction of examination-related stress in medical students: an exploratory randomized controlled trial. Advances in medical education and practice, 7, 497-504. doi: 10.2147/ AMEP.S110424

[11] Kumar Pandey, A., \& L Pandey, B. (2017). Neurophysiology of Social Conduct and Impact of Adverse Exposures. Avicenna Journal of Neuro Psycho Physiology, 4(1), 1-8. doi: 10.5812/ ajnp. 12452

[12] McAdams, D. P., \& Olson, B. D. (2010). Personality development: Continuity and change over the life course. Annual review of psychology, 61, 517-542. doi: 10.1146/ annurev.psych.093008.100507

[13] Meares, R., Gerull, F., Stevenson, J., \& Korner, A. (2011). Is self disturbance the core of borderline personality disorder? An outcome study of borderline personality factors. Australian \& New Zealand Journal of Psychiatry, 45(3), 214-222. doi: 10.3109/00048674.2010.551280

[14] Mendelevy`ch, V. D. (2001). Клиническая и медицинская психология: Практическое руководство [Clinical and Medical Psychology: Practical Guide]. Москва: МЕДпресс Moscow: MEDpress.

[15] Moroz, V. M., Makarov, S. Yu., Serebrennikova, O. A., \& Serheta. I. V. (2020). Навчальний стрес та психофрізіологічні критерії оцінки адаптаційних можливостей організму студентів закладів вищої медичної освіти [Educational stress and psychophysiological criteria for assessing the adaptive capacity of the body of students of higher medical education]. Вінниця: ТОВ "ТВОРИ" - Vinnytsya: TOV "TVORY".

[16] Orn, P. (1997). Stress and burnout among physicians. Similar problems in different health care systems. Lakartidningen, 94(22), 2052.
[17] Oxley, D. R., Smith, K. B., Alford, J. R., Hibbing, M. V., Miller, J. L., Scalora, M., ... \& Hibbing, J. R. (2008). Political attitudes vary with physiological traits. Science, 321(5896), 1667-1670. doi: $10.1126 /$ science. 1157627

[18] Pervin, L. A. (1999). The cross-cultural challenge to personality. In Y.-T. Lee, C. R. McCauley, \& J. G. Draguns (Eds.), Personality and person perception across cultures ( $p$. 23-41). Lawrence Erlbaum Associates Publishers.

[19] Petrov, M. E., Lichstein, K. L., \& Baldwin, C. M. (2014). Prevalence of sleep disorders by sex and ethnicity among older adolescents and emerging adults: relations to daytime functioning, working memory and mental health. Journal of adolescence, 37(5), 587-597. doi: 10.1016/ j.adolescence.2014.04.007

[20] Pohlmann, K., Jonas, I., Ruf, S., \& Harzer, W. (2005). Stress, burnout and health in the clinical period of dental education. European journal of dental education, 9(2), 78-84. doi: 10.1111/ j.1600-0579.2004.00359.x

[21] Raygorodskiy, D. Y. (2011). Практическая психодиагностика. Методики и тесты [Practical psychodiagnostics. Techniques and tests]. Самара: Издательский дом "Бахpax-M" - Samara: Publishing house "Bakhrakh-M".

[22] Schauer, M., \& Elbert, T. (2010). Dissociation following traumatic stress : Etiology and Treatment. Zeitschrift for Psychologie/ Journal of Psychology, 218(2), 109-127. doi: 10.1027/00443409/a000018

[23] Serheta, I. V., Bardov, V. H., Drezhenkova, I. L., \& Panchuk, O. Y. (2020). Гігієнічні нормативи рухової активності студентів закладів вищої медичної освіти та шляхи їі опmимізації [Hygienic standards of motor activity of students of higher medical education institutions and ways of its optimization]. Вінниця: ТОВ "ТВОРИ" - Vinnytsya: TOV "TVORY".

[24] Serheta, I. V., Panchuk, O. Y., \& Yavorovskyi, O. P. (2020). Гігієнічна діагностика професійної придатності студентів закладів медичної освіти (на прикладі стоматологічних спеціальностей) [Hygienic diagnostics of professional suitability of students of medical education institutions (on the example of dental specialties)]. Вінниця: TOB "TВOРИ" - Vinnytsya: TOV "TVORY".

[25] Tymoshchuk, O. V., Polka, N. S., \& Serheta, I. V. (2020). Hayкові основи комплексної гігієнічної оцінки якості життя та адаптаційних можливостей сучасної учнівської і студентської молоді [Scientific bases of complex hygienic assessment of quality of life and adaptive possibilities of modern pupil and student youth]. Вінниця: ТОВ "ТВОРИ" Vinnytsya: TOV "TVORY".

[26] Weber, K., Miller, G. A., Schupp, H. T., Borgelt, J., Awiszus, B., Popov, T., ... \& Rockstroh, B. (2009). Early life stress and psychiatric disorder modulate cortical responses to affective stimuli. Psychophysiology, 46(6), 1234-1243. doi: 10.1111/ j.1469-8986.2009.00871.x

[27] Welch, S. S., Linehan, M. M., Sylvers, P., Chittams, J., \& Rizvi, S. L. (2008). Emotional responses to self-injury imagery among adults with borderline personality disorder. Journal of consulting and clinical psychology, 76(1), 45-51. doi: 10.1037/ 0022-006X.76.1.45 